\title{
PERAN SELF-ESTEEM DAN STRESS TERHADAP HARASSMENT PADA PEMAIN ONLINE GAME DEWASA AWAL
}

\author{
Angeline Vivian Tjahyadi ${ }^{1}$, Ersa Lanang Sanjaya ${ }^{2}$ \\ E-mail:ersa.sanjaya@ciputra.ac.id ${ }^{2}$ \\ Fakultas Psikologi Universitas Ciputra Surabaya ${ }^{1,2}$
}

\begin{abstract}
The aim of this study is to examine the correlation between self-esteem and stress towards harassment behaviour in online gaming. There were 136 emerging adult participated in this study. They were all chosen using non-probability sampling technique. This study uses quantitative research method with causal research design. Each participant finished Rosenberg Self-Esteem Scale (RSES), Kessler Psychological Distress Scale, and The Video Game Harassment Scale from Fox and Tang. All scale was proven reliable where the alpha cronbach was 0.856 for RSES, 0.917 for Kessler Psychological Distress Scale, and 0.806 for The Video Game Harassment Scale. The results showed that there is a significant correlation between stress and harassment $(\mathrm{r}=0.197, \mathrm{p}=0.022)$. However, there is no significant correlation between self-esteem and harassment $(\mathrm{r}=-0.062, \mathrm{p}=0.472)$.
\end{abstract}

Keywords: Emerging adults, Harassment, Self-Esteem, Stress, Online Games.

\begin{abstract}
Abstrak
Tujuan dari penelitian ini adalah untuk menguji korelasi antara self-esteem dan stress terhadap perilaku harassment di online game. Ada 136 responden dewasa awal yang berpartisipasi dalam penelitian ini, mereka semua dipilih menggunakan teknik non-probability sampling. Penelitian ini menggunakan metode kuantitatif. Setiap partisipan diminta menyelesaikan Rosenberg Self-Esteem Scale (RSES), Kessler Psychological Distress Scale, dan skala The Video Game Harassment Scale milik Fox and Tang. Semua skala telah terbukti reliable dimana alpha cronbach untuk RSES adalah 0.856, 0.917 untuk Kessler Psychological Distress Scale, dan 0.806 untuk skala The Video Game Harassment Scale. Hasil menunjukan bahwa ada korelasi yang signifikan antara stress dan harassment $(\mathrm{r}=0.197, \mathrm{p}=0.022)$, dan tidak ada korelasi signifikan antara selfesteem dan harassment $(\mathrm{r}=-0.062, \mathrm{p}=0.472)$
\end{abstract}

Kata kunci: Dewasa awal, Online game, Harassment, Self-Esteem, Stress.

\section{PENDAHULUAN}

Dewasa ini, internet tidak hanya digunakan sebagai sarana untuk menggali informasi atau berinteraksi melalui media sosial. Kini, internet juga sering dimanfaatkan untuk bermain bersama (multi player) melalui online games. Fenomena bermain online games dapat ditemui pada anak muda hingga orang dewasa, dengan beragam jenis permainan, baik gratis maupun berbayar (Ramdhani, et al., 2018:55). Kemudahan akses internet, gawai yang semakin canggih, dan mudahnya bermain bersama tanpa dibatasi jarak dan waktu membuat online games semakin lekat pada banyak orang.

Pada tahun 2017, peminat online games di Indonesia menduduki posisi ke16 tertinggi di dunia. Dengan jumlah pemain mencapai 43,7 juta, potensi penghasilan dari online games $\mathrm{di}$ Indonesia mencapai Rp 11,9 Triliun. Ini menunjukan betapa tingginya minat 
penduduk Indonesia terhadap pemainan online games itu sendiri. Pemain online games sering digambarkan sebagai individu yang penyendiri. Namun nyatanya tidak lah demikian. Banyak online games yang harus dimainkan bersama orang lain, baik sebagai teman dan atau musuh. Perlunya bekerjasama, adanya penyesuaian gaya bermain, dan adanya kubu dalam online games memunculkan komunitas-komunitas di dalamnya. Hal ini menjadikan bermain online games sebuah aktivitas sosial (Weibel et al., 2008).

Banyak penelitian telah membahas dampak negatif dari online games. Salah satunya adalah pengaruhnya terhadap kemampuan bersosialisasi individu. Individu atau kelompok yang memainkan online games cenderung memiliki dunia baru di luar apa yang dijalaninya sehari-hari (Argestya, 2013). Pada titik tertentu pemain online games bisa menjadi tidak peduli dengan sistem nilai, moral dan norma yang digunakan di luar komunitas, atau dengan kata lain tidak lagi peduli pada aturan yang ada (esports.id, 2017).

Di Indonesia, banyak penelitian telah menemukan pengaruh online games dengan konten kekerasan dan dampaknya pada perilaku agresif, khususnya bagi remaja (Amanda, 2016; Ramadhani,
2019). Agresivitas ini dapat diekspresikan melalui tindakan harassment berupa kekerasan/ bullying. Harassment didefinisikan sebagai pelecehan secara umum. Kajian empiris (Tang \& Fox, 2016) menjelaskan bahwa pelecehan yang dilakukan bisa berupa kata kutukan, hinaan atau komentar yang menyinggung. Harassment biasanya dilakukan pemain karena ketidakpuasan dalam bermain. Ketidakpuasan ini mereka lampiaskan dengan menghina keterampilan/ kecerdasan seseorang, bersumpah serapah, hingga mengancam atau mengganggu kemajuan dalam permainan. Harassment dapat terjadi di banyak online games, terlepas dari jenis game yang dimainkan.

Fox \& Tang (2016) secara lebih lanjut mengungkap bahwa harrasment memiliki dua aspek, yakni general harassment dan sexual harassment. Dalam game, kedua aspek tersebut sering digunakan pelaku harassment dalam melecehkan pemain lain. Pelecehan yang dilakukan bisa termasuk komentar seksis (misalnya menyiratkan inferioritas atau ketidaksetaraan yang terkait dengan jenis kelamin), menghina kondisi fisik dan menggunakannya sebagai bahan lelucon. Selain komentar seksis, pelaku juga melontarkan komentar negatif 
menyinggung cara bermain atau kecerdasan pemain lainnya.

Dalam online games, pemain diijinkan untuk bergerak bebas secara anonimus. Mereka bisa menggunakan nama samaran/ palsu, menggunakan foto orang lain, bahkan bermain dengan akun orang lain. Hal ini membuat pelaku harassment tidak perlu merasa takut pada peraturan moral, limitasi, etika, ataupun konsekuensi dari perilaku mereka (Makarova \& Makarova, 2019) Pelaku dapat dengan bebas melakukan harassment pada pemain lain melalui fitur chat/ voice chat, dan tidak ada upaya yang bisa dilakukan oleh korban untuk menghentikannya.

Fox dan Tang (2016) menemukan bahwa semakin berpengalaman atau kompeten pemain online games, maka semakin besar juga potensinya untuk menjadi pelaku harassment. Makarova dan Makarova (2019) menyebutkan bahwa keinginan pemain untuk memainkan permainan sebaik mungkin bisa mendorong mereka menjadi egois, merasa superior, dan cenderung antisosial. Pemain yang merasa kompeten mengharapkan permainan yang selaras dengan kemampuan mereka, dengan demikian membuat mereka lebih kompetitif untuk meraih kemenangan.
Menurut penelitian dari Shores et al. (2014), pemain online games yang kompetitif juga memiliki tingkat toxicity lebih tinggi daripada mereka yang bermain hanya untuk kesenangan. Apa lagi ketika permainan yang dimainkan memiliki lawan dan harus dimainkan bersama dengan tim, seperti game Esport. Permainan tim yang baik sangat diperlukan untuk mendapatkan hasil permainan yang baik (Rambusch et al., 2007). Toxicity bisa muncul karena pemain yang kompetitif menyadari bahwa kesalahan bermain dari pemain lain akan mempengaruhi kemenangan. Tidak heran jika ada pemain yang saling menyalahkan anggota timnya ketika hasil bermain kurang memuaskan/ berujung pada kekalahan (Adachi et al., 2011).

Menyalahkan orang lain adalah perilaku hasil dari rendahnya self-esteem. Self-esteem didefinisikan sebagai evaluasi seseorang terhadap dirinya secara keseluruhan (Rosenberg, 1965) Evaluasi ini dapat bersifat positif maupun negatif secara.

$$
\text { Mulyana \& Afriani }
$$
menemukan bahwa individu dengan selfesteem yang rendah lebih mudah tersinggung dan menyakiti orang lain. Mereka memiliki tendensi untuk melakukan kejahatan/ kenakalan karena hal tersebut akan meningkatkan self- 
esteem mereka (Rosenberg et al., 1989)

Dalam penelitian yang lain, Rosenberg (1965) juga mengatakan bahwa orangorang dengan self-esteem yang rendah cenderung tidak dapat menerima kesalahan diri sendiri sehingga menunjukan impuls agresivitas yang lebih besar kepada orang lain. Agresivitas ini ditunjukan untuk menutupi rasa inferior atau sisi lemah yang dapat menurunkan self-esteem mereka. Dalam hal ini, munculnya perilaku harassment bisa jadi merupakan salah satu bentuk melindungi self-esteemnya saat menghadapi kekalahan atau permainan tim yang tidak maksimal.

Beberapa studi menemukan bahwa online games bisa menjadi sarana mengurangi stress (Russoniello et al., 2009). Online games yang terlihat menyenangkan bisa menjadi salah satu bentuk dari emotional coping stress. Sayangnya, ketika pemain mendapati permainannya atau anggota timnya tidak memberikan hasil yang dia inginkan, hal ini malah bisa menambahkan tingkat stress dari pemain itu sendiri.

Stres merupakan bentuk outcome dari interaksi antara individu dengan lingkungan yang dianggap membebani, sehingga melampaui kemampuan yang dimiliki (Piyeke, et al., 2014). Stres tersebut bisa dilatarbelakangi oleh kecemasan, kekhawatiran, tegang, merasa gagal, kesepian, kekecewaan, kesedihan dan perasaan negatif lain, dan tubuh yang senantiasa merasa tidak nyaman (malaise) saat online games berlangsung (McLean \& Griffiths, 2013). Stres yang tinggi membuat individu berpotensi menjadi pelaku harassment. Individu yang hidup pada lingkungan permainan yang tidak bersahabat (seperti tingginya tingkat kompetisi, tekanan untuk berprestasi, kemudahan untuk digantikan, dll) akan cenderung menjadi pelaku harassment (Andriani, et al., 2018).

Perilaku harassment tentu memiliki dampak bagi korban. Perilaku harassment yang dilakukan pemain secara tidak langsung menyatakan bahwa bagi pelaku, korban tidak layak untuk bermain di permainan (Yee, 2014). Korban harassment juga mungkin mengalami permasalahan emosi yang serius akibat merasa dipermalukan. Konsekuensi negatifnya termasuk mengalami tekanan emosional, menutup dan menarik diri dari media sosial serta dunia online games (Vitak, et al., 2017).

$$
\text { Berdasarkan data yang }
$$
didapatkan oleh Adl's Center on Technology and Society ditahun 2019, rata-rata lebih dari $60 \%$ pemain online game mengalami harassment. Hal ini 
tentu bukanlah permasalahan yang sederhana. Harassment dalam online games termasuk perilaku cyber-bullying dan perlu mendapatkan perhatian dan upaya intervensi yang sama dengan kasus bullying di dunia pendidikan.

Saat ini, penelitian di Indonesia mengenai perilaku kekerasan dan online games masih banyak membahas tentang pengaruh aspek-aspek online games (seperti durasi dan konten game) pada sikap agresif pemain (e.g. Amalia \& Syam, 2017; Dewi, 2020; Fasya et al., 2017; Musthafa et al., 2015; Satria, 2015). Masih belum banyak penelitian yang membahas mengenai faktor internal pemain dan perannya memicu perilaku harassment. Memahami faktor internal individu yang mempengaruhi tindak kekerasan sangatlah penting. Dengan mengetahui faktor internal individu, orangtua maupun instansi pendidikan dapat mengupayakan intervensi yang lebih bervariasi. Dengan demikian, mengurangi harassment dalam online games tidak selalu bergantung pada mengurangi durasi permainan.

Oleh sebab itu, penelitian ini bertujuan untuk menguji peranan selfesteem dan stress pada perilaku harassment. Alat ukur self-esteem yang dipakai dalam penelitian ini adalah Rosenberg Self-Esteem Scale (RSES).
Skor yang tinggi dalam pengukuran RSES menunjukkan bahwa semakin tinggi skor yang didapatkan subjek maka semakin tinggi pula tingkat self-esteem dalam diri subjek. Tingkat stress akan diukur menggunakan Kessler Psychological Distress Scale dalam 30 hari terakhir (Easton, et al., 2017).

Penelitian ini dilakukan sebagai pengujian apakah self-esteem dan stress berhubungan terhadap pelaku harassment pada pemain online games. Penelitian ini terfokus pada pemain online games dewasa awal, baik yang menggunakan Personal Computer (PC) maupun handphone.

\section{KAJIAN PUSTAKA}

\section{Harasment}

Merujuk pada kajian Fox dan Tang (2016), harassment dalam konteks beramain game melibatkan perilaku bermusuhan, seperti menghina keterampilan atau kecerdasan orang lain, mengganggu kemajuan mereka, bersumpah, atau mengancam mereka. Pelaku harassment dalam game online adalah individu gamers yang terlibat langsung dalam perilaku menghina dalam permainan.

Menurut Fox dan Tang (2016) aspekaspek dari harassment adalah

\section{General Harassment}


General harassment merupakan perilaku pelecehan yang bersifat umum, biasanya ditujukan kepada individu lain dalam game. Biasanya, general harassment termasuk mengomentari cara bermain orang lain, skill individu yang lain, dll.

\section{Sexual Harassment}

Sexual harassment merupakan perilaku pelecehan yang berbasis gender dan bersifat seksual. Biasanya, hal ini dilakukan pelaku harassement dengan melibatkan penargetan seseorang berdasarkan jenis kelamin, gender, atau identitas gender mereka. Dalam game, ini termasuk komentar seksis (misalnya menyiratkan inferioritas atau ketidaksetaraan yang terkait dengan jenis kelamin atau gender). Terkadang, pelaku memberikan perhatian seksual dengan melibatkan komunikasi yang jelas tentang hasrat seksual seperti mengusulkan atau menyiratkan aktivitas seksual.

\section{Stress}

Stres dapat didefinisikan sebagai sebuah keadaan yang dialami ketika ada sebuah ketidaksesuaian antara tuntutantuntutan yang diterima dan kemampuan untuk mengatasinya. Stres adalah keadaan dimana beban yang dirasakan seseorang tidak sepadan dengan kemampuan untuk mengatasi beban. Atau stres dinilai individu sebagai sesuatu yang membebani atau melampaui kemampuan yang dimiliki, serta mengancam kesejahteraan. Stres diakibatkan oleh adanya perubahanperubahan nilai budaya, perubahan sistem kemasyarakatan, tugas atau pekerjaan serta akibat ketegangan antara idealisme dan realita. Baik nyata maupun imajinasi, persepsi seseorang terhadap stres sebenarnya berasal dari perasaan takut atau marah. Perasaan ini dapat diekspresikan dalam sikap tidak sabar, frustasi, iri, tidak ramah, depresi, bimbang, cemas, rasa bersalah, dan khawatir (Easton, dkk., 2017).

\section{Self-Esteem}

Menurut Rosenberg

(1965)

menyatakan self-esteem evaluasi seseorang terhadap dirinya, baik positif maupun negatif, secara keseluruhan. Birk, dkk., (2015) menjelasakan 2 (dua) jenis pendekatan dalam memahami self-esteem, yaitu self-esteem global dan self-esteem spesifik. Kedua pendekatan self-esteem ini berbeda dalam segi pengukuran dan segi efektivitasnya. Self-esteem global menanamkan nilai tentang perasaan terhadap diri sendiri secara luas, sedangkan self-esteem spesifik menilai diri dari berbagai segi atau aspek. Rosenberg (1965) menambahkan bahwa self-esteem global adalah penilaian positif dan negatif terhadap diri sendiri secara menyeluruh. 
Rosenberg et al. (1995) juga mengatakan bahwa kedua jenis selfesteem ini penting, namun dengan alasan serta cara yang berbeda. Self-esteem spesifik sangat relevan diterapkan dalam hal perilaku, sedangkan self-esteem global lebih relevan untuk diterapkan pada hal kesejahteraan psikologis. Bila dikaitkan dengan intervensi interaksi dengan game online, Birk, dkk., (2015) menegaskan dengan menggunakan pendekatan selfesteem global daripada self-esteem spesifik. Hal ini dikarenakan intervensi dalam tingkat domain self-esteem spesifik menjadi terbagi-bagi dan tidak memberikan efek secara afektif. Sedangkan global self-esteem dapat mengena secara afektif dan cukup baik bila digunakan untuk mengintervensi. Maka dari itu, dalam penelitian ini, selfesteem yang digunakan adalah self-esteem global.

\section{METODE PENELITIAN}

Penelitian ini dilakukan dengan metode penelitian kuantitatif. Pengumpulan data dilakukan dengan menyebarkan kuisioner pada 136 responden berusia 18-25 tahun, memiliki pengalaman bermain online game setidaknya selama 2 tahun, dan berdomisili di Indonesia. Teknik pengambil sampel yang digunakan adalah non-probability sampling.

Setiap responen diminta untuk menyelesaikan 3 skala, yaitu The Video Game Harassment Scale (Fox \& Tang, 2013) untuk mengukur harassment, Rosenbeg Self-Esteem Scale (RSES) (Rosenberg, 1965) untuk mengukur selfesteem, dan Kessler Psychological Distress Scale (KPDS) (Kessler \& Mroczek, 1992; 1994; Kessler et al., 2002) untuk mengukur stress. Semakin tinggi skor individu pada

Penelitian ini memiliki tiga variable dalam pelaksaannya. Variabel harassment sebagai variabel dependen, variabel stress dan self-esteem sebagai variabel independen.

\section{The Video Game Harassment} Scale mengukur dua perilaku, yaitu general harassment dan sexual harassment. General harassment mengukur seberapa kuat individu melakukan harassment yang bersifat umum kepada orang lain. Semakin tinggi skor, menunjukkan semakin tinggi perilaku general harassment. Sexual harassment mengkur seberapa kuat individu melakukan perilaku harassment yang bersifat seksual terhadap orang lain. Semakin tinggi skor, menunjukkan semakin tinggi perilaku sexual harassment. 
Skala self-esteem merupakan skala hasil adaptasi dari alat ukur Rosenberg Self-Esteem Scale (1965) dimana skala bersifat unidimensi. Skala self-esteem pada penelitian ini berjumlah 10 aitem. Subjek penelitian diminta untuk mengisi skala tersebut dari angka 1 hingga 5 . Semakin tinggi angka berarti semakin tinggi tingkat self-esteem yang dimiliki. Sebaliknya, semakin rendah angka maka semakin rendah tingkat self-esteem yang dimiliki oleh subjek penelitian.

Skala stress merupakan skala hasil adaptasi dari alat ukur Kessler Distress Scale (Kessler \& Mroczec, 1994), dimana skala tersebut bersifat unidimensi. Skala stress pada penelitian ini berjumlah 10 aitem. Subjek penelitian diminta untuk mengisi skala tersebut dari angka 1 hingga 5. Semakin tinggi angka berarti semakin tinggi tingkat stress yang dimiliki. Sebaliknya, semakin rendah angka maka semakin rendah tingkat stress yang dimiliki oleh subjek penelitian.

Reliabilitas skala yang digunakan ditunjukan dengan nilai Cronbach's Alpha.

Skala harassment mendapat nilai $\alpha=$ 0.806 , skala self-esteem mendapat nilai $\alpha$ $=0.856$, dan skala stress mendapat nilai $\alpha$ $=0.917$. Uji normalitas penelitian ini menggunakan teknik KolmogorovSmirnov, uji korelasi menggunakan
Pearson Product Moment untuk menguji korelasi antar variabel. Keseluruhan uji menggunakan bantuan software IBM SPSS Statistics.

\section{HASIL DAN PEMBAHASAN}

Penelitian ini bertujuan untuk menguji korelasi antara stress dan selfesteem terhadap perilaku harassment. Hasil analisa korelasi antara self-esteem dan harassment menunjukan bahwa tidak ada hubungan yang signifikan antara self-esteem dan harassment $(r=-0.062, p$ $=0.472$ ) dimana artinya, tidak ada hubungan antara self-esteem dan harassment. Peneliti menduga, hal ini terjadi karena perilaku harassment yang ditunjukan bukanlah hasil dari rendahnya self-esteem, melainkan hasil dari pembelajaran sosial yang dilakukan oleh individu. Pryor et al. (1995) mengatakan bahwa pembelajaran sosial mencakup penyerapan norma dan kebiasaan yang dilakukan oleh orang-orang di sekitar individu. Dengan kata lain, perilaku harassment yang dilakukan bisa jadi adalah hasil penyerapan norma dan kebiasaan yang dilakukan oleh orangorang disekitar pemain.

Dalam penelitian yang dilakukan oleh Pryor (1992) mengenai pelecehan seksual, ia menemukan bahwa norma sosial tempat dimana kasus pelecehan 
seksual terjadi sangatlah penting. Kasus pelecehan seksual cenderung untuk terjadi jika situasi tersebut diizinkan secara sosial (Gutek, 1985). Hal ini juga berlaku pada perilaku harassment dalam online games. Jika tidak ada norma yang melarang atau mengontrol perilaku tersebut, maka pelaku pun akan cenderung dengan bebas melakukannya. Ditambah lagi dengan fakta bahwa mereka dapat melakukannya secara anonimus.

Tanpa ada norma yang tegas dari lingkungan sekitar individu, maka tidak ada konsekuensi yang jelas pula untuk perilaku bermasalah. Larwood et al. (1998) beragumen jika managemen atau pemimpin dalam organisasi menolerir atau memaafkan perilaku pelecehan, maka pelaku akan cenderung merasa bebas untuk melakukannya lagi. Penelitian yang dilakukan oleh Cotler et al (2016) mengenai cyberbullying juga menemukan bahwa "tidak takut hukuman" adalah penyebab maraknya cyberbulying. Pada kasus harassment dalam online games, jika anggota, lawan, atau pihak management pemain tidak memberikan sangsi yang membuat pelaku jera, perilaku harassment akan sulit untuk dihentikan (terlepas pelaku memiliki self-esteem yang tinggi maupun rendah).
Hasil lain dari penelitian ini menumukan adanya korelasi signifikan antara stress dan harassment secara keseluruhan $(\mathrm{r}=0.197, \mathrm{p}=0.022)$. Ketika dianalisa secara terpisah, stress memiliki korelasi signifikan dengan sexual harassment $(r=0.272, p=0.001)$ namun tidak berkorelasi dengan general harassment $(\mathrm{r}=0.251, \mathrm{p}=0.099)$.

Adanya korelasi antara stress dengan sexual harassment, namun tidak dengan general harassment, dapat disebabkan oleh beberapa hal. Pertama adalah karena harassment sendiri merupakan bentuk dari emotional coping stress para pelaku. Ketika permainan tidak berjalan sesuai dengan yang diharapkan, hal ini dapat memicu amarah/ agresivitas pelaku, yang kemudian dilampiaskan dengan melecehkan pemain lain. Selain itu, melakukan harassment masih belum di anggap sebagai masalah perilaku yang serius di dalam komunitas online games. Hal ini membuat tidak adanya konsekuensi sosial dari perilaku tersebut. Contohnya, ketika pemain mengutuk/ mengucapkan usmpah serapah, namun tidak ada anggota yang menegur dan atau malah setuju/ mendukung perilaku tersebut.

Kedua, mengapa stress berhubungan dengan sexual harassment 
bisa disebabkan karena faktor maskulinitas dan dominansi jenis kelamin dari sifat permainan. Penelitian sebelumnya menyebutkan bahwa kondisi lingkungan sekitar/ organisasi merupakan prediktor yang kuat untuk perilaku sexual harassment (e.g. Gutek, 1985; Larwood et al., 1988; Pryor, 1992). Saat ini, dunia online games memiliki rasio gender yang tidak seimbang. Baik pemain individu maupun komunitas, semua area di dominasi oleh laki. Pekerjaan yang maskulin dan rendahnya toleransi terhadap perilaku ofensif biasanya memiliki masalah sexual harassment yang jauh lebih besar (Steel \& Lee, 2007).

Tanpa disadari, sexual harassment bukan dilakukan karena secara intensional ingin melecehkan korban, namun karena pelaku sexual harassment dalam online games cenderung mencari target yang minoritas dalam lingkungan sekitarnya (Leskinen \& Cortina, 2014). Sexual harassment yang dilakukan untuk meningkatkan dominansi atas pihak yang dirasa lemah (e.g. kepada perempuan, atau laki-laki yang dirasa lebih inferior) menjadi salah satu cara untuk meluapkan stress dari pelaku.

\section{PENUTUP}

Kesimpulan dari penelitian ini adalah adanya hubungan signifikan antara stress dan harassment pada pemain online games dewasa awal $(\mathrm{r}=0.197, \mathrm{p}=0.022)$, namun tidak ada hubungan antara selfesteem dan harassment pada pemain game online dewasa awal $(\mathrm{r}=-0.062, \mathrm{p}=$ 0.472). Stress ditemukan berkorelasi sifnifikan dengan sexual harassment $(\mathrm{r}=$ 0.272, $\mathrm{p}=0.001)$, namun tidak dengan general harassment $(\mathrm{r}=0.251, \mathrm{p}=$ 0.099).

Hasil penelitian ini dapat dijadikan bahan pembelajaran maupun landasan dalam menciptakan rancangan-rancangan intervensi, baik dari dunia pendidikan, keluarga, maupun lembaga/ komunitas untuk mengurangi maraknya perilaku harassment. Untuk penelitian selanjutnya, peneliti menyarankan untuk menambahkan variable competitiveness. Dalam hal ini, sifat/ level kompetitif yang berbeda berpotensi untuk memberikan pengaruh yang berbeda pula untuk perilaku harassment.

\section{DAFTAR RUJUKAN}

Adachi, P. J., \& Willoughby, T. 2011. The effect of video game competition and violence on aggressive behavior: Which characteristic has the greatest influence?. Psychology of violence, 1(4), 259. 
Amalia, P., \& Syam, H. M. 2017. Hubungan Intensitas Bermain Game Online Berunsur Kekerasan Dengan Perilaku Agresif Anak di Banda Aceh. Jurnal Ilmiah Mahasiswa Fakultas Ilmu Sosial \& Ilmu Politik, 2(3)

Easton, S. D., Safadi, N. S., Wang, Y., Hasson, R. G. 2017. The Kessler Psychological Distress Scale: Translation And Validation Of An Arabic Version. Health and Quality of Life Outcomes.

Fasya, H., Yasin, S., Hafid, A., \& Amelia, A. F. 2017. Pengaruh Game Online Terhadap Tingkat Agresivitas Anak-anak dan Remaja di Kota Makassar (Studi Kasus di Kecamatan Tallo). Hasanuddin Student Journal, 1(2), 127-134.

Fox, J., \& Tang, W. Y. 2017. Women's experiences with general and sexual harassment in online video games: Rumination, organizational responsiveness, withdrawal, and coping strategies. New Media \& Society, 19(8), 1290-1307.

Fox, J., \& Tang, W. Y. 2013. Harassment in online video games and predictors of video game sexism. In Annual Conference of the National Communication Association.

Gutek, B. 1985. Sex And The Workplace. San Francisco: Jossey-Bass.

Kessler, R. C., Andrews, G., Colpe, L. J., Hiripi, E., Mroczek, D. K., Normand, S. L. T., Walters, E. E., \& Zaslavsky, A. M. 2002. Short screening scales to monitor population prevalences and trends in non-specific psychological distress. Psychological Medicine, 32(6), 959-976.

Kessler, R. C., \& Mroczek, D. 1994. Final versions of our non-specific psychological distress scale. University of Michigan. Ann Arbor: Survey Research Center of the Institute for Social Research.

Mulyana, S., Afriani. 2017 Hubungan Antara Self-Esteem dengan Smartphone Addiction pada Remaja SMA di Kota Banda Aceh. Jurnal Psikogenesis. 5 (2); 102-114.

Musthafa, A. E., Ulfa, N. S., Herieningsih, S. W., \& Pradekso, T. 2015. Pengaruh Intensitas Bermain Game Online dan Pengawasan Orang Tua Terhadap Perilaku Agresif Anak. Interaksi Online, 3(3).

Piyeke, P. J., Bidjuni, H., \& Wowiling, F. 2014. Hubungan tingkat stres dengan durasi waktu bermain game online pada remaja di manado. Jurnal keperawatan, 2(2).

Pryor, J. B. 1992. The Social Psychology Of Sexual Harassment: Person And Situation Factors Which Give Rise To Sexual Harassment. In Northwest Women's Law Center, Sex And Power Issues In The Workplace: An Interdisciplinary Approach To Understanding, Preventing, And Resolving Harassment: Conference proceedings (pp. 89105). Seattle, Washington: Northwest Women's Law Center.

Pryor, J. B., Giedd, J. L., \& Williams, K. B. 1995. A Social Psychological Model for Predicting Sexual Harassment. Journal of Social 
Issues. $\quad 51(1)$;

$69-$

84. doi:10.1111/j.1540-

4560.1995.tb01309.

Ramdhani, N., Wimbarti, S., Susetyo, Y. F. 2018. Psikologi Untuk Indonesia Tangguh dan Bahagia. Yogyakarta: UGM PRESS.

Rambusch, J., Jakobsson, P., \& Pargman, D. 2007. Exploring E-sports: A case study of game play in Counter-strike. In 3rd Digital Games Research Association International Conference:" Situated Play", DiGRA 2007, Tokyo, 24 September 2007 through 28 September 2007 (Vol. 4, pp. 157-164). Digital Games Research Association (DiGRA).

Reicher, S. D., Spears, R., Postmes, T., Kende, A. 2016. Disputing Deindividuation: Why Negative Group Behaviours Derive From Group Norms, Not Group Immersion. Behavioral and Brain Sciences, 39.

Rosenberg, M. 1965. Self Report Measures for Love and Compassion Research: SelfEsteem. Princeton, NJ Princeton.

Rosenberg, M., Schooler, C., \& Schoenbach, C. 1989. SelfEsteem and Adolescent Problems: Modeling Reciprocal Effects. American Sociological Review, 54(6), 1004.

Rosenberg, M. 1965. Society And The Adolescent Self-Image. Princeton, NJ: Princeton University Press.

Shores, K. B., He, Y., Swanenburg, K. L., Kraut, R., \& Riedl, J. 2014.
The identification of deviance and its impact on retention in a multiplayer game. In Proceedings of the 17th ACM conference on Computer supported cooperative work \& social computing (pp. 1356-1365).

Steel, P., Lee, K. 2007. A Meta-Analysis Of The Antecedents And Consequences Of Workplace Sexual Harassment. Personnel Psychology. 60(1); 127- 162.

Tang, W. Y., \& Fox, J. 2016. Men's harassment behavior in online video games: Personality traits and game factors. Aggressive Behavior, 42(6), 513-521.

Vitak, J., Chadha, K., Steiner, L., \& Ashktorab, Z. 2017. Identifying women's experiences with and strategies for mitigating negative effects of online harassment. In Proceedings of the 2017 ACM Conference on Computer Supported Cooperative Work and Social Computing (pp. 12311245).

Weibel, D., Wissmath, B., Habegger, S., Steiner, Y., \& Groner, R. 2008. Playing Online Games Against Computer-Vs. Human-Controlled Opponents: Effects On Presence, Flow, And Enjoyment. Computers in Human Behavior. 24(5); 2274-2291.

Yee, N. 2014. The Proteus paradox: How online games and virtual worlds change us-and how they don't. New Haven, CT: Yale University Press. 